\title{
Development of morphology and swimming in larvae of a coral-reef fish, the royal gramma, Gramma loreto (Grammatidae: Teleostei)
}

\author{
JEFFREY M. LEIS ${ }^{1,2}$, SUZANNE BULLOCK ${ }^{1}$, ALAIN DUDAY ${ }^{3}$, CHARLES GUION $^{3}$ \\ and RENÉ GALZIN ${ }^{2}$ \\ ${ }^{1}$ Ichthyology, Australian Museum, 6 College St, Sydney, NSW, 2010, Australia. E-mail jeff.leis@ austmus.gov.au \\ ${ }^{2}$ USR 3278 CNRS-EPHE, CRIOBE et CBETM, Université de Perpignan, 66860 Perpignan Cedex, France. \\ ${ }^{3}$ Lautan Production, Parc scientific, route des salins, 34140, Meze, France.
}

\begin{abstract}
SUMMARY: We used reared larvae of Gramma loreto sized 5.5 to $10.5 \mathrm{~mm}$ to study ontogeny of morphology and swimming. The larvae are slender to moderate in depth, with laterally compressed bodies, about 28 myomeres, a coiled gut that is not compact, extending to $50 \%$ to $60 \%$ of body length, an inconspicuous gas bladder, head spination limited to tiny preopercular spines, no pectoral-girdle spination, more spines than soft rays in the dorsal fin, and fins without elongate or early-forming elements. The limited pigment is most prominent along the base of the dorsal and anal fins. The development of critical speed (Ucrit) in G. loreto larvae was similar to that of other warm-water species, but speed ranged from 0.2 to 13.5 $\mathrm{cm} \mathrm{s}^{-1}$ (mean 7.3, SE 0.7, body lengths s${ }^{-1}$ ), which is relatively slow. Increase in speed with size was linear at $2.7 \mathrm{~cm} \mathrm{~s}^{-1}$ per $\mathrm{mm}$ increase in size. The actual and relative Ucrit of G. loreto were low, and only the four largest, fastest larvae would have been swimming in an inertial hydrodynamic environment. Therefore, for most of their pelagic larval duration the ability of G. loreto larvae to influence their dispersal by horizontal swimming is likely to be low compared with that of many other warm-water fish species.
\end{abstract}

Keywords: ontogeny, larva, critical speed, swimming, coral reef, dispersal.

\begin{abstract}
RESUMEN: DESARROLlo DE LA MORFOLOGía Y LA NATACIÓN EN LAS LARVAS DE UN PEZ DE ARRECIFES DE CORAL, GRAMA real, Gramma loreto (Grammatidae: Teleostei). - Hemos utilizado larvas cultivadas de Gramma loreto, $5.5-10.5 \mathrm{~mm}$, para estudiar el desarrollo ontogénico en morfología y natación. Las larvas son delgadas o moderamente gruesas, con cuerpos comprimidos lateralmente, con 28 miómeros, un tubo digestivo en espiral, no compacto y que se extiende hasta el 50-60\% de la longitud del cuerpo, con una vejiga natatoria inconspicua, espinas en la cabeza limitadas a diminutas espinas preoperculares, sin espinas en la pectoral, mayor número de espinas que de radios blandos en la aleta dorsal, y aletas sin elementos alargados. La pigmentación es limitada, siendo más prominente a lo largo de la base de las aletas dorsal y anal. El desarrollo de la velocidad crítica (Ucrit) en las larvas de G. loreto fue similar al de otras especies de aguas cálidas, sin embargo la velocidad varió de 0.2 a $13.5 \mathrm{~cm} \mathrm{~s}^{-1}$ (promedio 7.3, ES 0.7, longitud del cuerpo s ${ }^{-1}$ ), lo que es relativamente lento. El incremento de velocidad con la talla fue lineal a $2.7 \mathrm{~cm} \mathrm{~s}^{-1}$ por mm de incremento en talla. La Ucrit real y la relativa de $G$. loreto fue baja, y solamente las cuatro larvas más grandes y más rápidas, hubieran nadado en un ambiente hidrodinámico inercial. Por tanto, durante la mayor parte de su periodo larvario pelágico la capacidad de las larvas de G. loreto para influir en su dispersión por la natación horizontal es probablemente baja en comparación con muchas otras especies de peces de aguas cálidas.
\end{abstract}

Palabras clave: ontogenia, larva, velocidad crítica, natación, arrecifes de coral, dispersión.

\section{INTRODUCTION}

The early life history of the Basslets of the small perciform family Grammatidae is poorly documented, de- spite the fact that at least two species are widely reared for the aquarium trade. This family of two genera is confined to the tropical western Atlantic Ocean, where the five species of Gramma and eight of Lipogramma live 
on coral reefs (Mooi and Gill 2003, Victor and Randall 2010). Spawning behaviour and egg masses have been described in Gramma species, and morphology of eggs in Lipogramma species. Grammatid species spawn eggs that are held together in clusters by tendrils, and the egg clusters are placed in nests under rocks or overhangs, or in crevices or shallow depressions (Mooi 1990, Asoh and Yoshikawa 1996). The eggs of Gramma loreto are guarded by the male, and take 5 to 10 days to hatch (Asoh and Yoshikawa 1996, Moe 2009). Newly hatched larvae of Gramma loreto have been described briefly (Asoh and Yoshikawa 1996). Hardy (2005) summarizes what little is known of the early life history stages of this species. Development of larvae has not been described in any grammatid.

Similarly, although it is important for determining larval dispersal (Leis 2007), nothing is known of the development of swimming ability in grammatid larvae, or any other aspect of their behaviour, other than anecdotal observations of feeding in captivity on aquarist websites. In fact, the ontogeny of swimming ability has been studied in only 15 families of demersal marine teleosts (Leis 2010).

We used reared larvae to document morphological and swimming ontogeny in G. loreto. This information will allow grammatid larvae to be identified in plankton samples, will assist future studies of the relationships of the family, and will assist in determining the extent to which behaviour of $G$. loreto larvae may influence dispersal by horizontal swimming, and therefore population connectivity.

\section{MATERIALS AND METHODS}

Larvae were reared from captive brood stock at Lautan Production, Meze, France, where swimming measurements were taken. The tank with the adult brood stock contained two Gramma loreto and three Gramma melacara. The two species are readily separable by colour alone: G. loreto is purple anteriorly and yellow posteriorly, whereas G. melacara lacks yellow and is purple overall except for a black 'cap' anteriorly on head and nape. There are two colour forms of G. loreto that may constitute different species (A.C. Gill, personal communication; see colour photos in Kuiter and Debelius 2006): 1) the purple colour extends to the base of the pectoral fin and onto the first half of the spiny dorsal fin; and 2) the purple colour extends to the vicinity of the anus and covers nearly all of the spiny dorsal fin. The adult brood stock of $G$. loreto, which was obtained from Cuban waters, was of colour form 1. Adults spawned naturally, and newly hatched larvae were removed from the spawning tank to rearing tanks with constant illumination as, 'green water' and a temperature of $26^{\circ} \mathrm{C}$ to $28^{\circ} \mathrm{C}$. Constant illumination is a common rearing practice in the aquarium industry. For the first 5 days rotifers were supplied, and from 6 days after hatch (DAH), the larvae were fed with Artemia nauplii. We used larvae of two cohorts. No spawning or egg masses were ob- served, but newly hatched larvae were discovered on 11 September 2010 (cohort 1), and again on 25 September 2010 (cohort 2). All larvae that metamorphosed from both cohorts were purple anteriorly and yellow posteriorly, and were thus identifiable as G. loreto colour form 1. Larvae of cohort 1 were tested in a swimming chamber on 3 October 2010 (23 DAH), and larvae of cohort 2 on 10 October 2010 (15 DAH).

\section{Morphological development}

The specimens used in this study are lodged at the Australian Museum under collection numbers I.45582 (cohort 1) and I.45583 (cohort 2). The larvae were shipped to the Australian Museum and 3 to 4 months after initial fixation and a change of alcohol it was discovered that the larvae had shrunk an average of $7.25 \%$ from the sizes measured within $24 \mathrm{~h}$ of fixation. The sizes reported for swimming tests are the pre-shrinkage values because these are closest to the size of the larvae when swimming speed was measured. Sizes reported in the descriptions of morphological development are the post-shrinkage values because they were the sizes of the larvae when they were measured for descriptive purposes. Swimming was measured on 37 larvae (5.5$10.5 \mathrm{~mm}$ pre-shrinkage [5.1-9.4 mm post-shrinkage]: 1 preflexion, 5 flexion and 31 postflexion specimens). The description of morphological development was largely based on the same larvae as those tested in the swimming chamber, but five larvae that had not been so tested were included to fill in size gaps in the series. We attempted to include in the description of morphological development at least five larvae within each $1 \mathrm{~mm}$ size increment, but in some size increments insufficient larvae were available to achieve this.

Measurements and abbreviations follow Leis and Carson-Ewart (2004), with two additions. Dorsal Peduncle Length (PedL) was measured from the base of the last ray of the anal fin to the tip of the notochord until flexion was complete, and then to the level of the edge of the hypural plate. Maxilla length (MaxL) was measured along the axis of the maxilla from its anterior tip to the posterior end. Lengths are body length (BL). Percentages are of BL unless otherwise noted. Pigment refers to melanophores in preserved specimens. The larvae were examined under a dissecting microscope and measured using an ocular micrometer. Illustrations were prepared with the aid of a camera lucida.

\section{Critical speed}

A swimming chamber made of clear Perspex with 6 laneways, each $30 \mathrm{~mm}$ wide, $50 \mathrm{~mm}$ high and $180 \mathrm{~mm}$ long (Stobutzki and Bellwood, 1994), was used to measure swimming abilities of $G$. loreto larvae. A black line across the lid of the chamber provided the larvae with a point of reference while swimming. The chamber was identical to that of Stobutzki and Bellwood $(1994,1997)$, except that plankton mesh was used at the laneway ends 

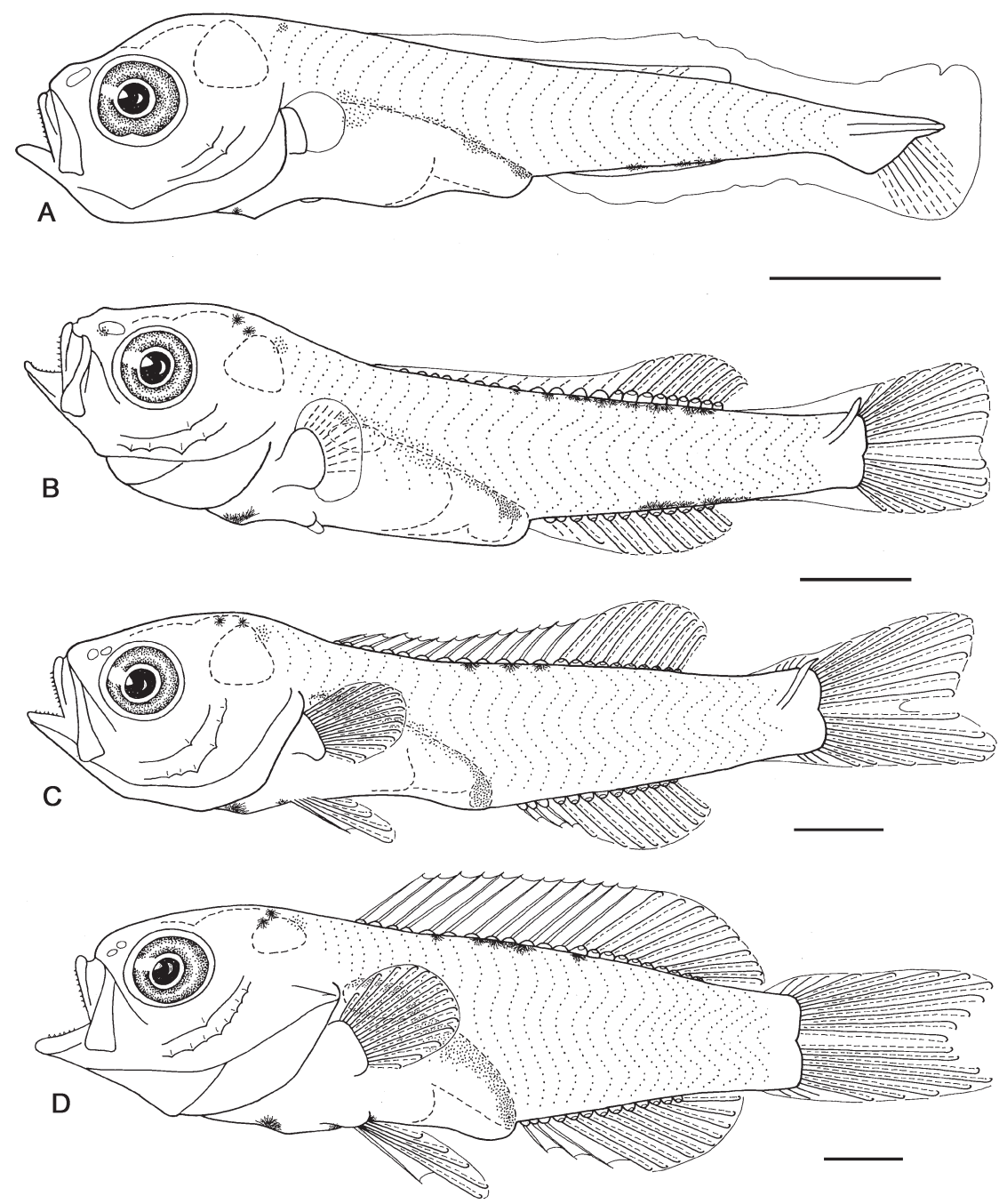

FIG. 1. - Reared larvae of Gramma loreto. A and B from cohort 2 (15 days after hatching), C and D from cohort 1 ( 23 days after hatching). Scale bars are $1 \mathrm{~mm}$. Body lengths are post-shrinkage. A, $5.1 \mathrm{~mm}$ preflexion larva (AMS I.45583-001); B, $6.6 \mathrm{~mm}$ postflexion larva (AMS I.45583-002); C, $8.1 \mathrm{~mm}$ postflexion larva (AMS I.45582-001); D, $9.4 \mathrm{~mm}$ postflexion larva (AMS I.45582-002).

to retain the small, slender larvae. The same chamber was used by previous Australian Museum-based studies, making the results directly comparable (see Leis $e t$ al., 2011). Even distribution of flow was achieved by a T-piece diffuser placed in the header portion of the chamber. Turbulence in the chamber was minimized by a 40-mm-long section of flow straighteners at the start of each laneway. This also minimized possible boundary layers. Previous measurements showed that water velocity in the $5 \mathrm{~mm}$ closest to the wall was not significantly different to that in the centre of the chamber (Stobutzki and Bellwood 1997, Stobutzki 1998, Fisher et al. 2000). Water flow speed was controlled by turning a calibrated valve. Flow rates were calibrated by recording the time taken for water flowing over the chamber's outlet weir to fill a container of known volume, divided by the cross-sectional area of the chamber. The average of 3 to 5 calibrations was used as the flow speed for a given valve angle on both 3 and 10 October. Critical speed (Ucrit), which quantifies maximum swimming speed over periods of minutes, was determined. Ucrit is a measure of prolonged rather than sustained speed (see Fisher and Leis 2009). Starting at 1.8 to $2.0 \mathrm{~cm} \mathrm{~s}^{-1}$ flow, speed in the chamber was increased by a target increment of $3.3 \mathrm{~cm} \mathrm{~s}^{-1}$ every 2 min until the fish were unable to swim against the flow. The time elapsed at the point when each larva drifted onto the downstream mesh $(t$ in the equation below) was recorded. Critical speed (Ucrit) was calculated following Brett (1964):

$$
\text { Ucrit }=U+\left(t / t_{\mathrm{i}} \times U_{\mathrm{i}}\right)
$$

where $U=$ penultimate speed, $U_{\mathrm{i}}=$ speed increment $\left(3.3 \mathrm{~cm} \mathrm{~s}^{-1}\right), t=$ time swum in the final speed increment, and $t_{\mathrm{i}}=$ the time interval for each velocity increment (2 min). Water temperatures in the swimming chamber were $26^{\circ} \mathrm{C}$ to $28^{\circ} \mathrm{C}$. Unfortunately, it was possible to measure swimming ability at the rearing facility only twice, and in the interim, larvae of cohort 1 had metamorphosed and settled. 
Following swimming in the chamber, larvae were euthanized and fixed in 70\% ethanol. Within $24 \mathrm{~h}$ of fixation, the larvae were examined under a dissecting microscope and $\mathrm{BL}$ was recorded $(\mathrm{BL}=$ standard length for postflexion larvae). Critical speeds are reported as both absolute speed $\left(\mathrm{cm} \mathrm{s}^{-1}\right)$ and relative speed, body lengths per second $\left(\mathrm{BL} \mathrm{s}^{-1}\right)$.

\section{RESULTS}

\section{Growth rates}

Larvae of 23 days after hatching (cohort 1) were 7.0 to $10.5 \mathrm{~mm}$ standard length (pre-shrinkage), and those of 15 days after hatching (cohort 2) were 5.4-7.7 mm standard length. Linear growth rates of the two cohorts were estimated based on the age of the larvae, the reported mean size at hatching of $3.38 \mathrm{~mm}$ (Asoh and Yoshikawa 1996), and the pre-shrinkage size of the larvae. On this basis, growth rates ranged from 0.15 to $0.31 \mathrm{~mm} \mathrm{~d}^{-1}$, with similar mean growth rates in the two cohorts of 0.22 and $0.23 \mathrm{~mm} \mathrm{~d}^{-1}$ (SE=0.01 for each).

\section{Morphological development (Fig. 1, Table 1)}

Larvae of $G$. loreto have a body that is elongate to moderate in depth and moderately compressed laterally, with 11-13+16-18=27-29 myomeres. Body depth at the pectoral base increases from about $18 \% \mathrm{BL}$ in our smallest larva to about $30 \%$ in the largest, with a similar increase in depth at the anus of $12 \%$ to $26 \% \mathrm{BL}$. The gut is loosely coiled with little ontogenetic change in the position of the anus. Pre-anal length is $53 \%$ to $63 \%$ BL. The inconspicuous swim bladder is located over the anterior portion of the gut. The head increases in relative size: about $28 \%$ to $30 \%$ BL before flexion is complete, reaching about $35 \% \mathrm{BL}$ at about $7.5 \mathrm{~mm}$, and a maximum of $38 \% \mathrm{BL}$ at $9.4 \mathrm{~mm}$. The snout is short and the mouth moderately oblique. The maxilla is slightly longer than the eye diameter, and is $35 \%$ to $45 \%$ of head length. Small, triangular teeth are present along the full length of the premaxilla and initially only the anterior portion of the lower jaw, although by 9.4 $\mathrm{mm}$, most of the lower jaw is armed with teeth. The round eye is moderate to large (31\% to $40 \%$ of head length), with no clear ontogenetic change in relative size. The nasal pit begins to roof over at about $7 \mathrm{~mm}$, and two nostrils may be present in specimens as small as $7.4 \mathrm{~mm}$, but not in ones as large as $8.1 \mathrm{~mm}$. Spination on the head is limited to very small spines on the inner $(n=0-1)$ and outer $(n=1-9)$ borders of the preopercle. A single small spine on the inner border of the preopercle is present in all specimens, except two of the three largest. The spines on the outer border are 3 by the end of flexion, about 4 to 5 by $7 \mathrm{~mm}$, and up to 8 to 9 by 9 $\mathrm{mm}$. A minority of specimens are asymmetrical, with a difference of one preopercle spine between the left and right sides. A weak opercular spine is present in the largest larvae. The pectoral girdle lacks spination.
Notochord flexion commences at about $5.5 \mathrm{~mm}$, and the smallest fully flexed larva is $5.8 \mathrm{~mm}$. Incipient rays first appear in dorsal, anal and pectoral fins during the flexion stage, and full compliments of elements are present in dorsal and anal fins by about $7 \mathrm{~mm}$, and in pectoral fins by about $7.5 \mathrm{~mm}$. The spines in the dorsal fin form after the soft rays, and are initially much shorter than the rays, but by $9.4 \mathrm{~mm}$ the spines and rays are about equal in length. The ultimate spine in both dorsal and anal fins transforms from the first ray between 7 and $7.5 \mathrm{~mm}$. All fin spines are slender and smooth, and none are particularly produced. The pelvic fin buds are first evident during the flexion stage, the first rays are present at about $6.5 \mathrm{~mm}$, and a full complement of elements is present at about $7.6 \mathrm{~mm}$. At $7.6 \mathrm{~mm}$, the pelvic fin reaches about one half to two thirds of the way to the anus, and at about $8 \mathrm{~mm}$, the tip of the fin reaches the anus. No scales are present on any larva.

The larvae are lightly pigmented. All larvae have an internal cap of pigment over the gas bladder and along the length of the gut. In the smallest larvae, there is a gap in the pigment along the gut, but the pigment is continuous in most specimens. At the posterior dorsal surface of the mid-brain are 1 to 4 melanophores on each hemisphere (only one larva with 4), with no ontogenetic trend in numbers. Four postflexion larvae also have a single melanophore on the mid-dorsal surface of the midbrain, and a 7.6-mm larva has a single melanophore on the forebrain. A single internal melanophore is present on the dorsal surface of the hindbrain, although this is increasingly difficult to see in larger larvae. However, a flexion larva of $6.1 \mathrm{~mm}$ has two such melanophores, and the melanophore is absent in four postflexion larvae. A single melanophore is present on the under surface of the nasal capsule in most larvae of less than $7.2 \mathrm{~mm}$, but not in larger larvae. A single melanophore is present at the angle of the lower jaw in 10 of 26 larvae between 6 and $9 \mathrm{~mm}$. A single melanophore is present at the cleithral symphysis in all larvae, with the following exceptions: 3 of 5 flexion larvae have 2 melanophores, and one has none; a single postflexion larva $(5.9 \mathrm{~mm})$ has no cleithral melanophore. One or two melanophores are present at the base of the pelvic fin in all larvae larger than 7.2 larvae, and $33 \%$ of smaller larvae. Pigment along the base of the dorsal fin on the tail is present in half of preflexion and flexion larvae and all post-flexion larvae. This consists of up to 9 melanophores on each side of the fin, often distributed asymmetrically. Although the number of melanophores in this series at any size varies, the maximum number seems to be highest between 6.6 and 8.0 $\mathrm{mm}$, and there is an anterior movement of the pigment, so in the largest larva it is almost entirely distributed along the base of the spiny portion of the dorsal fin. The pigment series along the base of the anal fin and posteriorly onto the ventral midline is less consistent. Larvae smaller than $7 \mathrm{~mm}$ have an average of 3.7 melanophores in this series, but may have 0 to 6 . Most larvae larger than $7 \mathrm{~mm}$ have no melanophores in this series, but may have as many as 4. However, see the Discussion section 
TABLE 1. - Morphometric and meristic values of reared larvae of Gramma loreto. Measurements (in mm) are post-shrinkage (see Methods). Abbreviations: BL, body length; PAL, pre-anal length; HL, head length; ED, eye diameter; SnL, snout length; BD (P1), body depth at Pectoral-fin base; BD (anus), body depth at anus; PedL, dorsal length of caudal peduncle; MaxL, length of maxilla. D, dorsal; A, anal; P1, pectoral; P2, pelvic. For fins [n] indicates numbers of incipient rays or spines, and (I) indicates a ray transforming into a spine. Preop, preopercular. Inner and outer refer to the borders of the pre-opercular bone: a range in values indicates bilateral asymmetry. In the body of the Table, $d$ indicates damaged.

\begin{tabular}{|c|c|c|c|c|c|c|c|c|c|c|c|c|c|c|c|c|}
\hline Stage & Cohort & $\mathrm{BL}$ & PAL & HL & ED & $\mathrm{SnL}$ & $\begin{array}{l}\text { BD } \\
\text { (P1) }\end{array}$ & $\begin{array}{c}\mathrm{BD} \\
\text { (anus) }\end{array}$ & PedL & MaxL & D fin & A fin & P1 fin & $\mathrm{P} 2$ fin & $\begin{array}{l}\text { Preop } \\
\text { inner }\end{array}$ & $\begin{array}{r}\text { spines } \\
\text { outer }\end{array}$ \\
\hline eflexion & 2 & 5.1 & 2.8 & 1.4 & 0.5 & 0.3 & 1.0 & 0.6 & - & 0.6 & 0 & 0 & 0 & 0 & 1 & 1 \\
\hline exion & 2 & 5.4 & 3.1 & 1.6 & 0.6 & 0.3 & 1.1 & 0.8 & 1.0 & 0.6 & [10] & [6] & [6] & bud & 1 & 1 \\
\hline Flexion & 2 & 5.5 & 2.9 & 1.6 & 0.6 & 0.3 & 1.1 & 0.8 & - & 0.6 & 0 & 0 & 0 & bud & 1 & 2 \\
\hline Flexion & 2 & 5.7 & 3.0 & 1.7 & 0.6 & 0.4 & 1.1 & 0.7 & - & 0.6 & [5] & [8] & [3] & bud & 1 & 1 \\
\hline Flexion & 2 & 5.8 & 3.3 & 1.6 & 0.6 & 0.4 & 1.1 & 0.9 & - & 0.6 & anlage & anlage & 0 & bud & 1 & 1 \\
\hline Flexion & 2 & 6.1 & 3.5 & 1.9 & 0.6 & 0.4 & 1.3 & 1.0 & 1.2 & 0.7 & [9] & {$[9]$} & [9] & bud & 1 & $2-3$ \\
\hline Postflexion & 2 & 5.8 & 3.5 & 1.9 & 0.6 & 0.5 & 1.3 & 1.0 & 0.9 & 0.8 & [10] & [10] & [5] & bud & 1 & 3 \\
\hline Postflexion & 2 & 5.9 & 3.4 & 1.7 & 0.6 & 0.4 & 1.2 & 1.0 & 1.0 & 0.6 & [10] & [11] & 0 & bud & 1 & 1 \\
\hline ostflexion & 2 & 5.9 & 3.5 & 1.8 & 0.7 & 0.4 & 1.2 & 1.0 & 1.0 & 0.7 & {$[\mathrm{I}, 10]$} & {$[\mathrm{I}, 10]$} & 0 & bud & 1 & 2 \\
\hline Postflexion & 2 & 6.0 & 3.6 & 1.8 & 0.6 & 0.5 & 1.4 & 1. & 1.0 & 0.8 & {$[\mathrm{I}, 8]$} & {$[10]$} & [3] & bud & 1 & 3 \\
\hline Postflexion & 2 & 6.1 & 3.9 & 2.0 & 0.7 & 0.5 & 1.3 & 1.0 & 1.0 & 0.8 & I[IV] 7 7[3] & $\mathrm{I}[\mathrm{I}], 8[2]$ & [8] & bud & 1 & 4 \\
\hline stflexion & 2 & 6.2 & 3.5 & 1.9 & 0.7 & 0.4 & 1.3 & 1.1 & 1.1 & 0.7 & {$[\mathrm{I}], 8[1]$} & {$[\mathrm{I}], 7[3]$} & [8] & bud & 1 & 2 \\
\hline Postflexion & 2 & 6.2 & 3.8 & 2.1 & 0.7 & 0.6 & 1.4 & 1.1 & 1.1 & 0.8 & {$[\mathrm{III}], 6[3]$} & $\mathrm{I}, 7[2]$ & [9] & bud & 1 & 4 \\
\hline Postflexion & 2 & 6.3 & 3.9 & 2.0 & 0.8 & 0.5 & 1.4 & 1.1 & 1.0 & 0.8 & X, 9 & $\mathrm{II}(\mathrm{I}), 10$ & [10] & bud & 1 & 3 \\
\hline Postflexion & 2 & 6.5 & 4.1 & 1.9 & 0.7 & 0.5 & 1. & 1.2 & 1.0 & 0.8 & $\mathrm{II}[\mathrm{I}], 6[3]$ & II, 10 & [9] & bud & 1 & 4 \\
\hline Postflexion & 2 & 6.5 & 3.8 & 2.1 & 0.7 & 0.5 & 1.3 & 1.0 & 1.1 & 0.8 & {$[\mathrm{IV}], 9$} & [II], 10 & $5[3]$ & bud & 1 & $1-2$ \\
\hline stflexion & 2 & 6.6 & 3.9 & 2.2 & 0.7 & 0.7 & 1.4 & 1.1 & 1.1 & 0.7 & [VIII], 7[2] & [II], 9[1] & [7] & bud & 1 & 3 \\
\hline Postflexion & 2 & 6.6 & 3.8 & 2.1 & 0.7 & 0.6 & 1.4 & 1.1 & 1.1 & 0.8 & [XII], 9 & [II], 10 & [10] & bud & 1 & 4 \\
\hline Postflexion & 1 & 6.6 & 3.7 & 2.1 & 0.8 & 0.4 & 1.5 & 1.2 & 1.1 & 0.8 & XI, 10 & $\mathrm{II}(\mathrm{I}), 10$ & $9[3]$ & $\mathrm{I}, 2[2]$ & 1 & $5-6$ \\
\hline Postflexion & 1 & 6.7 & 3.7 & 2.0 & 0.8 & 0.4 & 1.4 & 1.2 & 1.1 & 0.9 & XI, 10 & II(I), 8 & & {$[2]$} & 1 & 4 \\
\hline Postflexion & 1 & 6.8 & 3.9 & 2.3 & 0.8 & 0.6 & 1.5 & 1.3 & 1.2 & 1.0 & VII, 10 & II, 9 & 14 & $\mathrm{I}, 2[2]$ & 1 & 4 \\
\hline stflexion & 2 & 7.0 & 3.9 & 2.3 & 0.8 & 0.5 & 1. & 1.5 & 1.1 & 0.9 & IX, 9[1] & $\mathrm{II}(\mathrm{I}), 9$ & $7[3]$ & {$[\mathrm{I}, 4]$} & 1 & 4 \\
\hline Postflexion & 1 & 7.2 & 4.1 & 2.3 & 0.8 & 0.4 & 1.6 & 1.3 & 1.2 & 1.0 & IX $(\mathrm{I}), 9$ & II(I), 8 & $10[3]$ & $\mathrm{I}, 2[2]$ & 1 & 5 \\
\hline Paflexion & 2 & 7.2 & 4.2 & 2.0 & 0.8 & 0.4 & 1. & 1.3 & 1.1 & 0.9 & IX, $9[1]$ & II, 9 & $12[3]$ & $2[2]$ & 1 & 4 \\
\hline ostf & 1 & 7.4 & 4.6 & 2.8 & 1.0 & 0 & 1. & 1.6 & 1.3 & 1.0 & $\mathrm{XI}[\mathrm{I}], 10$ & III, 10 & $10[3]$ & $\mathrm{I}, 4[1]$ & 1 & 6 \\
\hline Postflexion & 1 & 7.6 & 4.6 & 2.7 & 1.0 & 0.7 & 1.7 & 1.6 & 1.3 & 1.0 & XI, 9 & III, 10 & 14 & I,5 & 1 & 5 \\
\hline . & 1 & 7.8 & d & 2.6 & 1.0 & 0.5 & 1.8 & d & 14 & 1.0 & d 10 & III, 10 & 14 & I,5 & 1 & 4 \\
\hline Postf & 1 & 7.8 & 4.4 & 2.8 & 1.0 & 0 & 1. & 1.4 & 1.4 & 1.0 & XI, 10 & III, 10 & 13 & $\mathrm{I}, 5$ & 1 & 4 \\
\hline Pos & 1 & 7.8 & 4.6 & 2.7 & 0.9 & 0.6 & 1. & 1.4 & 1.4 & 1.0 & XII, 10 & III, 10 & 15 & $\mathrm{I}, 5$ & 1 & 4 \\
\hline & 1 & 8.0 & 5.0 & 2. & 1 & & 2 & 1. & 1. & 1. & & III 0 & $13[1]$ & $\mathrm{I}, 5$ & 1 & 5 \\
\hline Postflexion & 1 & 8.1 & 4.8 & 2.8 & 0.9 & 0.7 & 1.7 & 1.5 & 1.4 & 1.0 & XII, 10 & III, 9 & 15 & I,5 & 1 & 6 \\
\hline & 1 & 8.1 & 4.4 & 2.8 & 1.0 & 0.7 & 1. & 1.5 & 1.4 & 1.1 & & III, 10 & 15 & I,5 & 1 & 7 \\
\hline & 1 & 8.1 & 4.6 & 2. & 0. & 0. & 1. & 1.6 & 1.3 & 1.1 & XII, 9 & III, 10 & 14 & $\mathrm{I}, 5$ & 1 & 6 \\
\hline Pos & 1 & 8.8 & 5.5 & 3.0 & 1.1 & 0.7 & 2. & 2.2 & 1.3 & 1.3 & XII, 10 & III, 10 & 15 & I,5 & 1 & 7 \\
\hline & 1 & 9. & 5.7 & 3. & 1. & 0 & 2. & 2.1 & 1. & 1.2 & & III, 9 & 14 & $\mathrm{I}, 5$ & 0 & 9 \\
\hline Postf & 1 & 9.0 & 5.5 & 3.3 & 1.2 & 0. & 2. & 2.1 & 1.5 & 1.3 & XII, 10 & III, 10 & 15 & I,5 & 0 & 5 \\
\hline Postflexion & 1 & 9.4 & 5.9 & 3.6 & 1.2 & 0.8 & 2.8 & 2.4 & 1.1 & 1.5 & XII, 10 & III, 10 & 15 & I,5 & 1 & 8 \\
\hline
\end{tabular}

about possible between-cohort differences in pigment. No other pigment was found. When alive, all larvae had an overall very pale red-orange colour, but this quickly disappeared after preservation.

Photos of three transitional larvae $(10.2-10.7 \mathrm{~mm}$ standard length) of $G$. loreto captured in a crest net by Cormac Nolan at Turneffe Reef, Belize $\left(17^{\circ} 18^{\prime} \mathrm{N}\right.$, $87^{\circ} 48^{\prime} \mathrm{W}$ ) on 15 August 2006 were provided by B.C. Victor (pers. comm.). These specimens (Fig. 2), which lack scales (B.C. Victor, pers. comm.), have general body proportions similar to the largest reared larva (body depth is $c a$. 30-32\% of standard lenght) except that the pelvic fin in the $10.7 \mathrm{~mm}$ specimen is much longer, reaching past the origin of the anal fin and approaching the form of the fin in adults. The transitional larvae still have some larval pigment consisting of 4 to 5 large melanophores along the base of the dorsal fin in the 10.2 and $10.7 \mathrm{~mm}$ specimens (none in the $10.3 \mathrm{~mm}$ specimen) and a single, internal melanophore at the base of the anal fin. The 10.3 and $10.7 \mathrm{~mm}$ specimens also have aspects of juvenile pigment which are most developed in the larger one (an ocellus on the dorsal fin anteriorly, and peppery melanophores on the head and trunk extending almost to the anus: this pigment pattern is consistent with colour form 2). The juvenile pigment and fin meristics (B.C. Victor, pers. comm.) confirm the identification of G. loreto, colour form 2, whereas the reared larvae are colour form 1.

\section{Swimming development}

Critical speed ranged from 0.2 to $13.5 \mathrm{~cm} \mathrm{~s}^{-1}$. In cohort $1(7.7-10.5 \mathrm{~mm})$, there was a significant, positive linear relationship between Ucrit and size $\left(R^{2}=0.43\right.$, $P=0.002, \mathrm{n}=20$, Fig. 3). In cohort $2(5.5-7.7 \mathrm{~mm})$, the relationship was similar, but was not significant $\left(R^{2}=0.18, P=0.087, \mathrm{n}=17\right.$, Fig. 3$)$. There was high variation in Ucrit among individuals at any size. In particular, the largest four larvae of cohort 2 had some of the fastest and slowest Ucrits of that cohort. In each cohort, speed increased at a rate of about $2.7 \mathrm{~cm} \mathrm{~s}^{-1}$ per $1 \mathrm{~mm}$ increase in size. When the two cohorts were combined, 


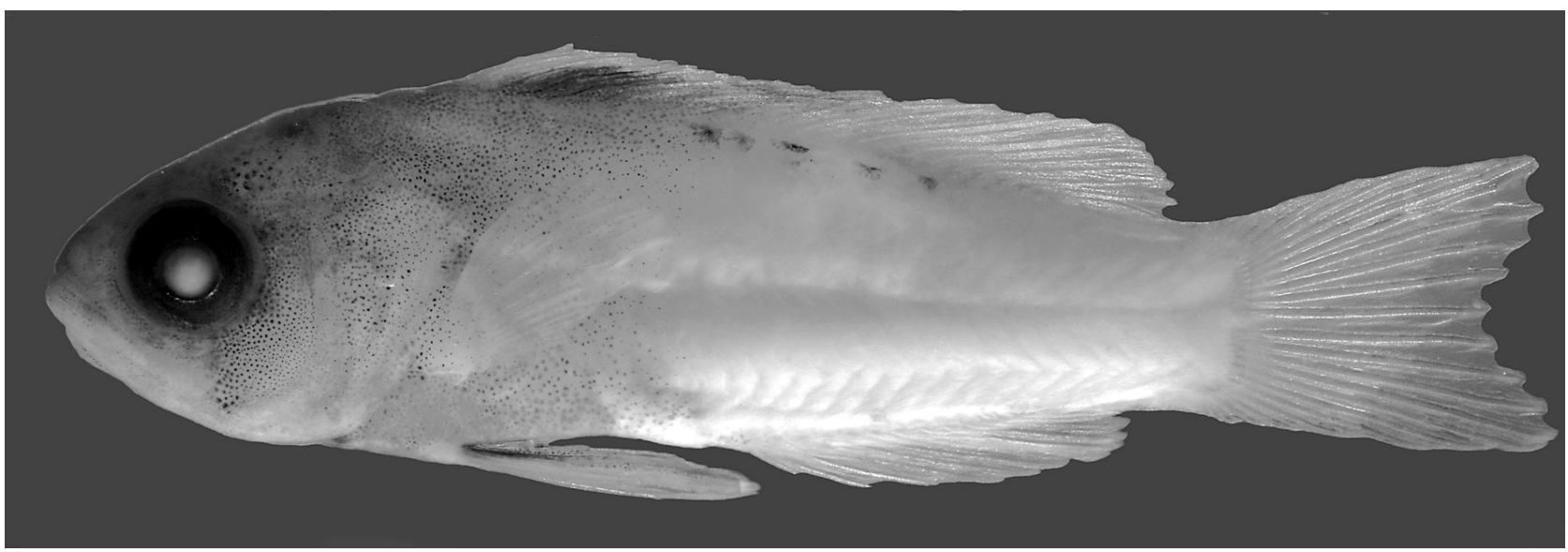

FIG. 2. - Transitional Gramma loreto $(10.7 \mathrm{~mm})$ captured by crest net at Turneffe Reef, Belize. Photo by B.C. Victor.

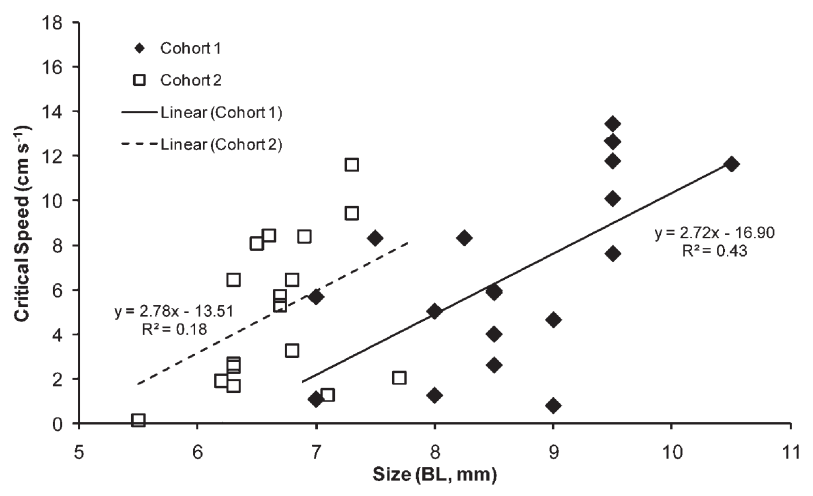

FIG. 3. - Development of critical speed in two cohorts of Gramma loreto larvae. The $95 \% \mathrm{CI}$ for the slope of each regression line is cohort $1,2.72 \pm 1.62$, and cohort $2,2.78 \pm 3.24$. Body lengths are pre-shrinkage.

the resulting relationship was significant $(P=0.002)$, but the regression explained only $26 \%$ of the variation in speed with size, and the rate of increase in speed was $1.6 \mathrm{~cm} \mathrm{~s}^{-1}$ per $1 \mathrm{~mm}$ increase in size $(95 \% \mathrm{CI} \pm 0.9)$.

When expressed as relative Ucrit $\left(\mathrm{BL} \mathrm{s}^{-1}\right)$, there was no significant relationship between size and speed $\left(R^{2}=0.07\right)$. Mean relative Ucrit was 6-8 $\mathrm{BL} \mathrm{s}^{-1}$ over 6 to $9 \mathrm{~mm}$, but increased to mean values of $9-11 \mathrm{BL} \mathrm{s}^{-1}$ for larvae of 9 to $11 \mathrm{~mm}$. The overall average relative Ucrit was 7.3 (SE 0.7) BL s ${ }^{-1}$, and the fastest larva (7.3 $\mathrm{mm})$ was $15.9 \mathrm{BL} \mathrm{s}^{-1}$.

Depending on the size increment, the fastest larvae had speeds ranging from little greater than average for their size to as much as $6 \mathrm{~cm} \mathrm{~s}^{-1}$ faster than average. The smallest difference between mean and fastest was in larvae smaller than $7 \mathrm{~mm}$, but the greatest difference was found in larvae only slightly larger $(7-8 \mathrm{~mm})$. For larvae larger than $7 \mathrm{~mm}$, the fastest larvae averaged about $3 \mathrm{~cm} \mathrm{~s}^{-1}$ faster than the mean.

\section{DISCUSSION}

The wild transitional larvae of $10.7 \mathrm{~mm}$ from Belize had an otolith-based pelagic larval duration estimate of about 20 days after hatching (B.C. Victor, pers. comm.). Applying the same assumptions as those used here, this would constitute an overall linear growth rate of $0.37 \mathrm{~mm} \mathrm{~d}^{-1}$. A wild larva therefore had a growth rate greater than the mean for reared larvae, but similar to that of the fastest-growing reared larvae. It must be kept in mind, however, that the reared larvae were exposed to constant illumination, which may have influenced their growth rates.

The only previous published description of $G$. loreto larvae is an illustration of a newly hatched 3.4-mm-BL reared larva (Asoh and Yoshikawa 1996). This larva, characterized by Hardy (2005) as "a typical period with no distinguishing features", had no developed fin rays, no head spination, and pigment limited to the dorsal surface of the gut between the swim bladder and the anus. Its proportions were similar to those of our smallest larva (preflexion, $5.4 \mathrm{~mm}$ ), but our smallest larva has two, tiny preopercular spines, and dorsal and anal fin anlagen, plus several forming caudal rays. Our $5.4 \mathrm{~mm}$ larva has a similar gut pigment to the $3.4 \mathrm{~mm}$ larva, but also has pigment along the base of the anal fin and near the cleithral symphysis.

Larvae of Gramma are relatively generalized in development, with few obvious specializations to pelagic existence. They are slender to moderate in depth, with a laterally compressed body, about 28 myomeres, a coiled gut that is not compact, extending to $50 \%$ to $60 \% \mathrm{BL}$, an inconspicuous gas bladder, head spination limited to tiny preopercular spines, no pectoral-girdle spination, more spines than soft rays in the dorsal fin, and fins that lack elongate or early-forming elements. Pigment is limited and is most prominent on the tail along the base of the fins.

There were some minor pigment differences between the two cohorts: in general cohort 2 larvae were more heavily pigmented than cohort 1 larvae. However, cohort 1 larvae were older and mostly larger than cohort 2 larvae, and there was very limited overlap in size between the two cohorts (6.6-7.2 $\mathrm{mm}$ post-shrinkage), so it is difficult to determine which differences are size- or age-related, and which are cohort-related. The flexion and postflexion stage cohort 2 larvae had 
a melanophore on each nasal capsule, although some of the larger cohort 2 larvae lacked a melanophore on one of the nasal capsules. In contrast, all cohort 1 larvae lacked nasal capsule melanophores. Pigment on the ventral midline of the tail constituted 0-1 melanophores (mostly 0 ) in cohort 1 larvae, all of which were postflexion. Preflexion and flexion stage cohort 2 larvae had 2 to 4 ventral midline melanophores on the tail, and postflexion larvae had 3 to 6 such melanophores. Pigment along the base of the dorsal fin was less extensive in cohort 1 larvae, with 1 to 9 melanophores, compared with 3 to 9 melanophores in cohort 2 postflexion larvae (but 0-3 melanophores in preflexion and flexion-stage larvae). Four larvae of each cohort were available within the size-range overlap, and for all three pigment groups mentioned there was no overlap in the number of melanophores between cohorts. Each cohort on its own displayed no clear overall ontogenetic trend in melanophore number, but when combined, an ontogenetic decrease in melanophores at the nasal capsule and along the base of the anal fin emerged. The number of dorsal melanophores, in contrast, appeared to reach a maximum in the combined cohorts at about 6.5 to $8 \mathrm{~mm}$, and then declined ontogenetically, but there was a great deal of variation in dorsal melanophore number at any particular size. Therefore, it seems most likely that the apparent differences in pigmentation between cohorts were, in fact, due to the difference in age and size of the larvae in the two cohorts.

Within their area of occurrence, G. loreto larvae are most likely to be confused with apogonids, haemulids, labrids, some blennioids, particularly tripterygiids, and presumably other grammatids. The lack of a conspicuous swim bladder, the presence of a continuous dorsal fin and the presence of at least 27 myomeres will separate $G$. loreto larvae from apogonids. Haemulids have more head spination, and have more soft rays than spines in the dorsal fin, and 26 myomeres. All cooccurring labrid larvae lack head spination and have $7+7$ caudal rays. Most labrid genera have 26 or fewer myomeres, more soft rays than spines in the dorsal fin and few, if any, melanophores. Exceptions are the genera Bodianus, Clepticus and Lachnolaimus, which have meristic values similar to G. loreto and often are more heavily pigmented than other labrid larvae. The blennioids have a shorter pre-anal length and usually more myomeres and dorsal- and anal-fin elements than G. loreto. Larvae of other grammatids are unknown, but are likely to be very similar to $G$. loreto larvae.

Gramma loreto is reported to have 27 to 28 vertebrae (Hardy 2005), and larvae would thus be expected to have 27 to 28 myomeres. Our larvae had 27 to 29 myomeres. Whether this apparent discrepancy is due to the fact that the reported range does not include all natural variation (Hardy did not report a sample size), or is an effect of the rearing conditions, we cannot say. Fin-ray meristic values of the larvae are within the reported range of G. loreto.
Gramma loreto larvae are similar in general morphology to pseudochromid larvae, and to a lesser extent to plesiopid larvae. Both these families are restricted to the Indo-Pacific, but both are thought to be relatively close relatives of grammatids (Mooi 1990). However, other than a general similarity in body shape and gut morphology, there are no clear larval specializations shared by the three families.

There was no obvious connection between speed and morphological development in G. loreto larvae. The caudal fin was complete by about $6 \mathrm{~mm}$ and dorsal and anal fins were complete by about $8 \mathrm{~mm}$. However, it is clear from Figure 3 that a clear increase in Ucrit starts at about $9.5 \mathrm{~mm}$, which is well after the median fins are complete. From about this size (corresponding to about $8.8 \mathrm{~mm}$ post-shrinkage) there was a strong increase in body depth from about $20 \%$ to $22 \%$ BL to $27 \%$ to $30 \%$ BL (Table 1). This would result in a large increase in musculature and propulsive area, and probably contributed to the increase in critical speed.

The development of swimming ability in G. loreto is similar to that of other warm-water demersal species in that the overall increase in speed with size was linear, and the rate of increase in speed was within the range reported for other species (Leis 2010). However, the actual and relative Ucrit values attained by G. loreto are low, and because G. loreto settles at a relatively small size (about $10 \mathrm{~mm}$ BL, based on specimens captured by crest nets, B.C. Victor, pers. comm.), it will have less ability to influence dispersal outcomes by horizontal swimming than many other species will. On the other hand, $G$. loreto hatches from demersal eggs at a relatively large size and is better developed than species from pelagic eggs at hatching, so it may be able to swim sooner after hatching than larvae from pelagic eggs. Dispersal modelling suggests that what happens during the period soon after propagules enter the water column is very important to dispersal outcomes (J.M. Leis and L.B. Mason, unpublished), so the moment when swimming begins may be as important as the speeds involved. Further, we know nothing about the vertical distribution, orientation abilities or swimming endurance abilities of $G$. loreto larvae, and all these behaviours have an important bearing on dispersal trajectories and outcomes. Until these aspects of behaviour are better understood, it would be premature to conclude that $G$. loreto larvae have limited influence on their dispersal.

Most of the larvae tested (21 of 37) would have been swimming in an intermediate hydrodynamic environment (Reynolds Number [Re] $=300$ to 1000, Leis 2006) at their critical speed. In an intermediate hydrodynamic environment, both viscous and inertial forces are influential. The smallest larva swimming at Re greater than 300 , below which viscous forces predominate, was 6.3 $\mathrm{mm}$. Only the four largest, fastest larvae would have been swimming in an inertial environment ( $\operatorname{Re}>1000)$. Swimming in a viscous environment is energetically inefficient, so one would not expect sustained swim- 
ming in larvae with Re lower than 300. Even though larvae as small as $6.3 \mathrm{~mm}$ were out of a viscous environment, others as large as $8.5 \mathrm{~mm}$ had a Re of 208, and still swam in a viscous environment.

Critical speed is a forced measure of swimming ability, and not the speed at which larvae swim in the sea (Fisher and Leis 2009). However, significant relationships between Ucrit and in situ speed have been reported, so it is possible to predict in situ speed from these. In larvae of seven tropical and warm-temperate species, a median ratio of 0.65 between in situ speed and Ucrit was found (Leis 2010). Using this value, one would expect $G$. loreto larvae to have in situ speeds about two thirds the critical speeds reported here, for a maximum in situ speed of $8.8 \mathrm{~cm} \mathrm{~s}^{-1}$ and a relative speed of $4.8 \mathrm{BL} \mathrm{s}^{-1}$. These are at the low end of reported in situ speeds for larvae of warm-water species, but similar to speeds of sciaenid larvae of similar size, and fast enough to be influential in the context of dispersal outcomes (Leis 2006). Given the small size at settlement of G. loreto, and its rather slender body (and thus low propulsive area and muscle mass), such swimming performance is not unexpected. At settlement, this species should have a capacity to influence dispersal by horizontal swimming similar to that of some labrids of similar size and morphology (Leis et al. 2011), and of sciaenids, but less than that of many other warm-water species. However, at the predicted in situ speed, no G. loreto larva we tested would have Re greater than 1000 , and more than half would be swimming in a viscous hydrodynamic environment.

A perennial question is how morphology, behaviour and swimming performance of reared larvae compare with those of wild larvae. Unfortunately, there is no information on any aspect of larval biology for $G$. loreto, or any confamilial. Similarly, until wild larvae of grammatids of the same size become available, we cannot determine how our reared larvae might differ from them. As the larvae were reared under constant illumination, the ontogenetic sequence of morphological or behavioural events may have been altered. However, the wild transitional specimens from Belize are similar to the largest reared larvae, and this suggests that morphological differences will be small.

Larvae of $G$. loreto have fairly straightforward morphological development with few specializations for pelagic life. Swimming also develops in a straightforward (linear) manner, but neither absolute nor relative Ucrit is high and, as in other species, variation in speed at size is high. Swimming abilities of larval $G$. loreto can allow them to influence their dispersal in a manner similar to that of several other families, but their swimming abilities are poor compared with similar-size larvae of many other families.

\section{ACKNOWLEDGEMENTS}

This research was carried out while JML was Visiting Professor at EPHE, Université de Perpignan, and was supported by a grant to JML from the Australian Academy of Science. This research was carried out under permits issued by CNRS to the USR 3278 CNRS/ EPHE team to conduct research experiments in the field and laboratory at all locations (under the "Hygiène et Sécurité" section). Thanks are due to Amanda Hay for registering the larvae, and to B.C. Victor for providing Figure 2, other illustrations and pelagic larval duration information.

\section{REFERENCES}

Asoh K., Yoshikawa T. 1996. Nesting behavior, male parental care, and embryonic development in the fairy basslet, Gramma loreto. Copeia 1: 1-8.

Brett J.R. 1964. The respiratory metabolism and swimming performance of young sockeye salmon. J. Fish. Res. Board Can. 21: 1183-1226.

Fisher R., Bellwood D.R., Job S.D. 2000. Development of swimming abilities in reef fish larvae. Mar. Ecol. Prog. Ser. 202: 163-173.

Fisher R., Leis J.M. 2009. Swimming performance in larval fishes: from escaping predators to the potential for long distance migration. In: Domenici P., Kapoor B.G. (eds.) Fish locomotion: an etho-ecological approach. Science Publishers, Enfield, New Hampshire, USA, pp. 333-373.

Hardy J.D. 2005. Grammatidae: Basslets. In: Richards W.J. (ed.) Early stages of Atlantic fishes: an identification guide for the western central north Atlantic, Vol 1. Taylor \& Francis, Boca Raton, Florida, pp. 1341-1351.

Kuiter R.H., Debelius H. 2006. World atlas of marine fishes, Vol. IKAN-Unterwasserarchiv. Frankfurt. 720 pp.

Leis J.M. 2006. Are larvae of demersal fishes plankton or nekton? Adv. Mar. Biol. 51: 59-141.

Leis J.M. 2007. Behaviour as input for modelling dispersal of fish larvae: behaviour, biogeography, hydrodynamics, ontogeny, physiology and phylogeny meet hydrography. Mar. Ecol. Prog. Ser. 347: 185-193.

Leis J.M. 2010. Ontogeny of behaviour in larvae of marine demersal fishes. Ichthyol. Res. 57: 325-342.

Leis J.M., Carson-Ewart B.M. (eds.) 2004. The larvae of Indo-Pacific coastal fishes: a guide to identification (Fauna Malesiana Handbook 2, 2nd edition), Vol 2. Brill, Leiden. 850 pp.

Leis J.M., Hay A.C., Gaither M.R. 2011. Swimming ability and its rapid decrease at settlement in wrasse larvae (Teleostei: Labridae). Mar. Biol. 158: 1239-1246.

Moe M.A. 2009. Marine aquarium handbook: beginner to breeder. TFH Publications. Neptune City, New Jersey. 351 pp.

Mooi R.D. 1990. Egg surface morphology of Pseudochromoids (Perciformes: Percoidei), with comments on its phylogenetic implications. Copeia 455-475.

Mooi R.D., Gill A.C. 2003. Grammatidae. Basslets. In: Carpenter K.E. (ed.) The living marine resources of the western central Atlantic FAO species identification guide for fishery purposes, Vol 2. FAO, Rome, pp. 1370-1373.

Stobutzki I.C. 1998. Interspecific variation in sustained swimming ability of late pelagic stage reef fish from two families (Pomacentridae and Chaetodontidae). Coral Reefs 17: 111-119.

Stobutzki I.C., Bellwood D.R. 1994. An analysis of the sustained swimming abilities of pre- and post-settlement coral reef fishes. J. Exp. Mar. Biol. Ecol. 175: 275-286.

Stobutzki I.C., Bellwood D.R. 1997. Sustained swimming abilities of the late pelagic stages of coral reef fishes. Mar. Ecol. Prog. Ser. 149: 35-41.

Victor B.C., Randall J.E. 2010. Gramma dejongi, a new basslet (Perciformes: Grammatidae) from Cuba, a sympatric sibling species of G. loreto. Zool. Stud. 49: 865-871.

Scient. ed.: M.P. Olivar.

Received May 4, 2011. Accepted October 14, 2011.

Published online February 3, 2012. 